\title{
Revision of the Jurassic lithostratigraphy of the Danish Subbasin
}

BY

OLAF MICHELSEN

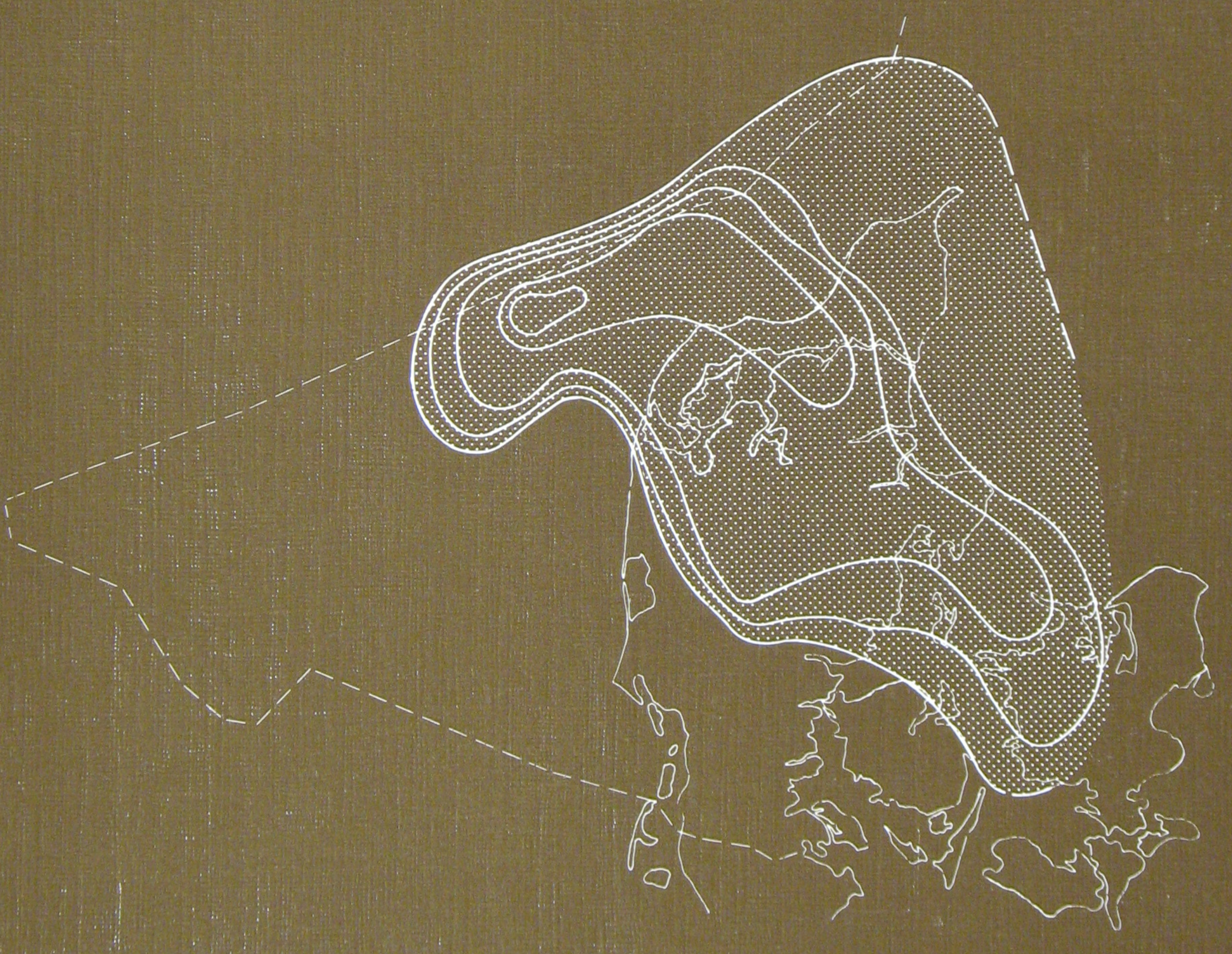

Danmarks Geologiske Undersøgelse · København 1989 


\section{Revision of the Jurassic lithostratigraphy of the Danish Subbasin}

BY

OLAF MICHELSEN

Danmarks Geologiske Undersøgelse · København 1989 
Key words:

Danish Subbasin, Jurassic, lithology, bio- and lithostratigraphy

\section{Vignette:}

Map of the Fjerritslev Formation

DGU Serie A nr. 24.

ISBN 87-88640-43-4

ISSN 0901-0270

Oplag: 1000

Tryk: AiO Tryk as, Odense

Tegning: Eva Melskens

Dato: $12-10-1989$

Olaf Michelsen,

DGU, Thoravej 8 .

DK-2400 København NV

Redaktion: Leif Banke Rasmussen

(C) Danmarks Geologiske Undersøgelse

Thoravej 8, DK-2400 København NV

I kommission hos: Geografforlaget ApS.

Ekspedition: Fruerhøjvej 43, 5464 Brenderup

Telefon: 64441683 


\section{Contents}

Abstract

Introduction

Background and purpose.

Material and methods

Geological setting .

Well descriptions .

Hyllebjerg-1

Kvols-1

Oddesund-1

Rødding-1

Skive-1
Lithostratigraphic discussion 17

Definition of the members of the Fjerritslev

Formation................. 17

Haldager Formation, abandoned .......... 18

Haldager Sand Formation, new rank ........ 20

Flyvbjerg Formation, new rank .......... 20

Bream Formation, abandoned ........... 20

Børglum Formation, new rank ........... 20

Frederikshavn Formation, new rank ....... 20

Acknowledgements................. 22

References ..................... 23 


\section{Abstract}

The lithology and stratigraphy of the Jurassic sequence in the Danish Subbasin is described from 5 wells situated in the central region of the Danish Subbasin. The chronostratigraphic subdivision of the Lower Jurassic Fjerritslev Formation is discussed and modified in the light of new biostratigraphical and lithostratigraphical data from the five well sections. The Jurassic lithostra- tigraphic subdivision is amended. The F-Ia, F-Ib, F-II, F-III, and F-IV members of the Fjerritslev Formation are redescribed and defined in relation to the reference section in the Hyllebjerg-1 well. The Haldager and Bream Formations are abandoned. The Haldager Sand, Flyvbjerg, Børglum, and Frederikshavn Members are elevated to the rank of formations. 


\section{Introduction}

\section{Background and purpose}

This paper deals with the Jurassic sequence in the five wells, Hyllebjerg-1, Kvols-1, Oddesund-1, Rødding-1, and Skive-1, which were drilled onshore in North Jylland by Danbor in 1976 (fig. 1). They were the first wells in which sidewall cores were taken at regular intervals and modern, high quality petrophysical measurements $(\operatorname{logs})$ were performed. It was, therefore, natural to examine these well sections to re-evaluate the stratigraphy. The wells are located in the centre of the Danish Subbasin and thus may be regarded as typical of the basin evolution. New detailed analyses of ostracod faunas from the Fjerritslev Formation have been carried out on the Hyllebjerg-1 (Michelsen in press, pl. 1) and Kvols-1 well sections. The lithostratigraphic subdivision of the entire Jurassic sequence and the biostratigraphic data are presented in fig. 5 .
Modification of the lithostratigraphic subdivision is based on the high quality logs. A detailed log-analysis of the Fjerritslev Formation led to the identification of $\log$-sequences that are chronostratigraphically significant (Michelsen in press). This analysis was used in the lithostratigraphic study to identify hiati or condensed sequences. Aspects of the Early Jurassic basin development derived from this log-sequence analysis are described in Michelsen (in press), together with new interpretations of environmental conditions.

\section{Material and methods}

The investigation of the five well sections was based on cuttings samples, sidewall cores, and petrophysical measurements. Generally, three to four sidewall cores per hundred metres were taken (see fig. 5). In reservoir

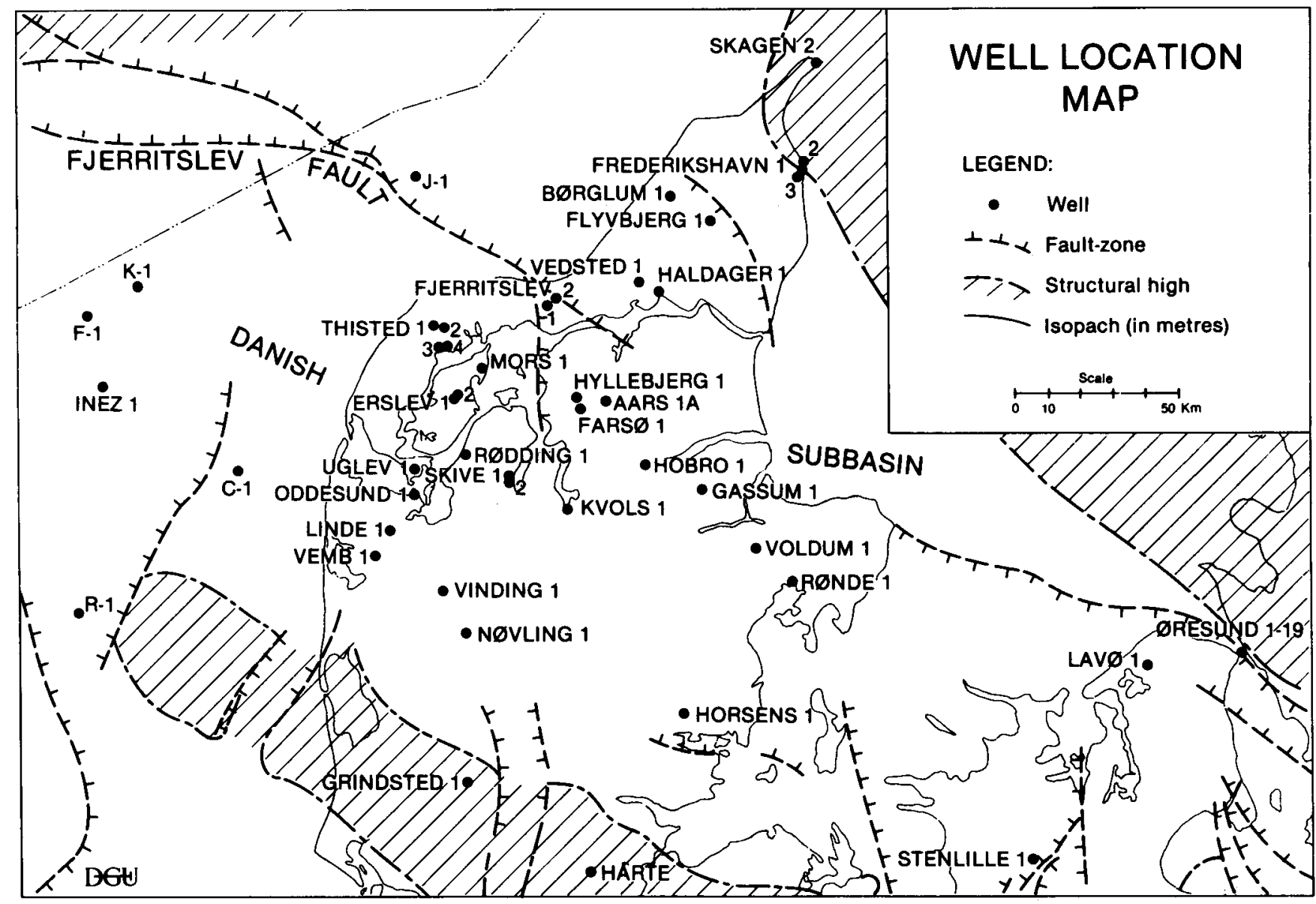

Fig. 1: Structural map of the Danish Subbasin showing well locations. 


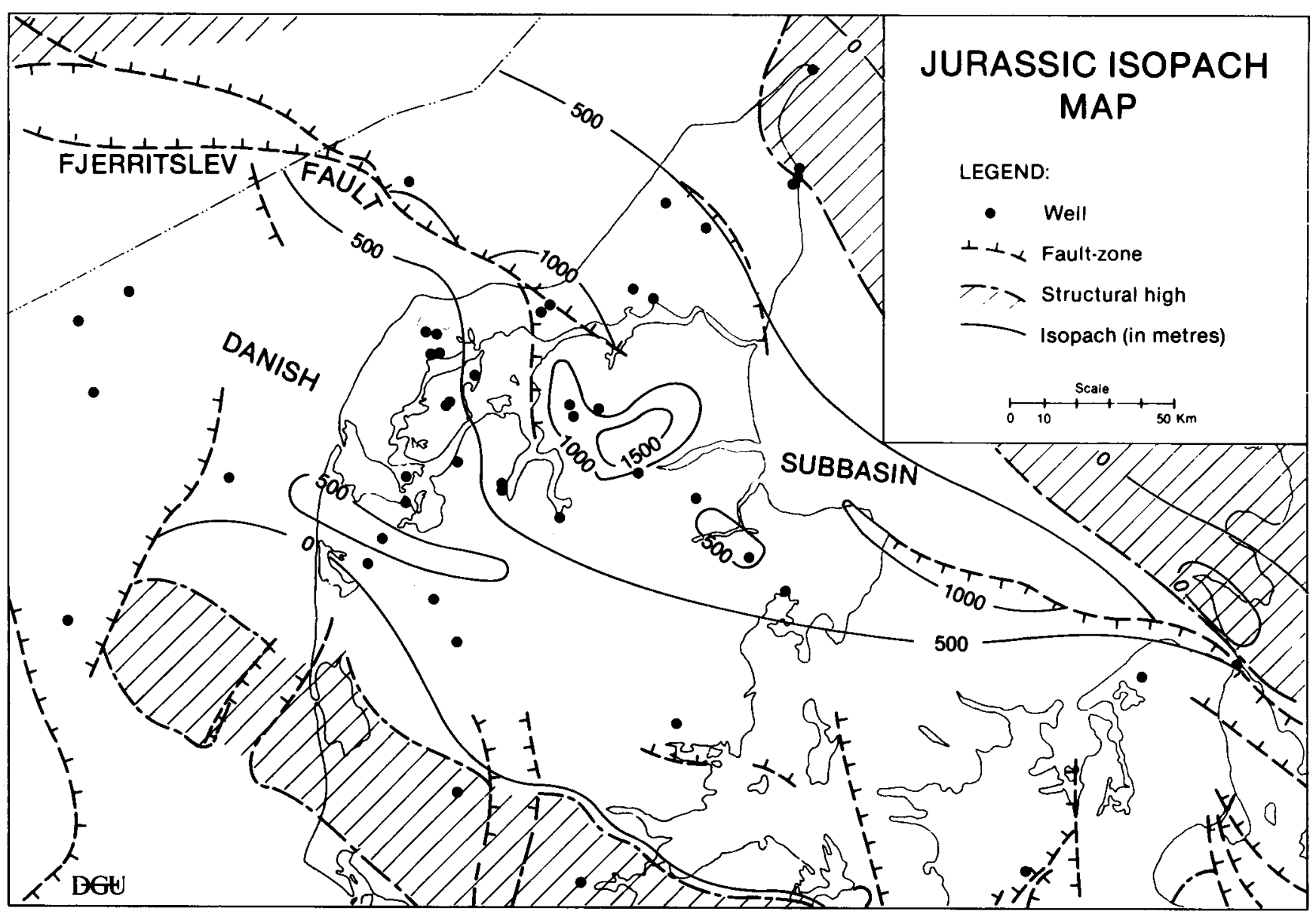

Fig. 2: Generalized isopach map of the Jurassic sequence in the Danish Subbasin. Well locations are indicated; well names are shown on fig. 1 .

sequences the density of sidewall cores is greater. Generally, cuttings were sampled at intervals of 10 feet. The samples together with analyses of the petrophysical measurements were used for determination of the lithology. Furthermore, the cuttings samples were used for biostratigraphic analyses in the Hyllebjerg-1, Kvols-1, Oddesund-1, and Rødding-1 wells. The lithologic description presented below is based on description of the sidewall cores, in which studies of sedimentary structures were possible in only a few cases. The sidewall cores were described by Søren Priisholm, and the biostratigraphic work was undertaken by the author.

Petrophysical measurements were used to determine the lithology and to locate the lithostratigraphic boundaries; logs used in this context were primarily the gamma ray, sonic velocity, neutron, and density logs. The SP and resistivity (RES) logs were used to correlate with older wells drilled in North Jylland and thus are included in fig. 4 alongside the gamma ray (GR) and sonic velocity (ITT) logs.

\section{Geological setting}

The five wells, Hyllebjerg-1, Kvols-1, Oddesund-1, Rødding-1, and Skive-1, are located in the central part of the Danish Subbasin, an area that has been strongly influenced by mobilization of Zechstein salt (figs. 1 and 3). Salt movements started during the Late Triassic (Carnian), and diapirism mainly took place in the $\mathrm{Ju}$ rassic (Boldreel 1985). All five wells are located on local highs at the top-Gassum Formation level (fig. 3).

The Kvols- 1 and Skive-1 wells were drilled within the region that has more than $500 \mathrm{~m}$ of Jurassic sediments, as calculated from seismic data (fig. 2). The Hyllebjerg-1 well was drilled in a graben like structure which constituted a major depo-centre during the Triassic. It is located close to the area of maximum thickness $(>1500 \mathrm{~m}$ ) of Jurassic sediments (fig. 2). The well is not sited on a major diapiric salt structure. The salt flowed into the surrounding diapirs, but minor local bodies accumulated along faults within the pre-Zechstein sequence. The Hyllebjerg-1 well was drilled on one such small accumulation of Zechstein salt, a few hundred metres thick (Sørensen 1986).

The Kvols-1 well is located on the top of a small salt pillow, which came into existence during the Jurassic Early Cretaceous. The halokinesis seems to have influenced sedimentation primarily in Middle to Late Jurassic times, although probably starting in the latest Early Jurassic (Sørensen 1986). The Skive-1 well was drilled on the northern flank of a large salt pillow. The structure formed during the Sinemurian to Kimmeridgian, 


\section{REFLECTION ISOCHRONE CONTOURS ON}

\section{TOP GASSUM FORMATION}

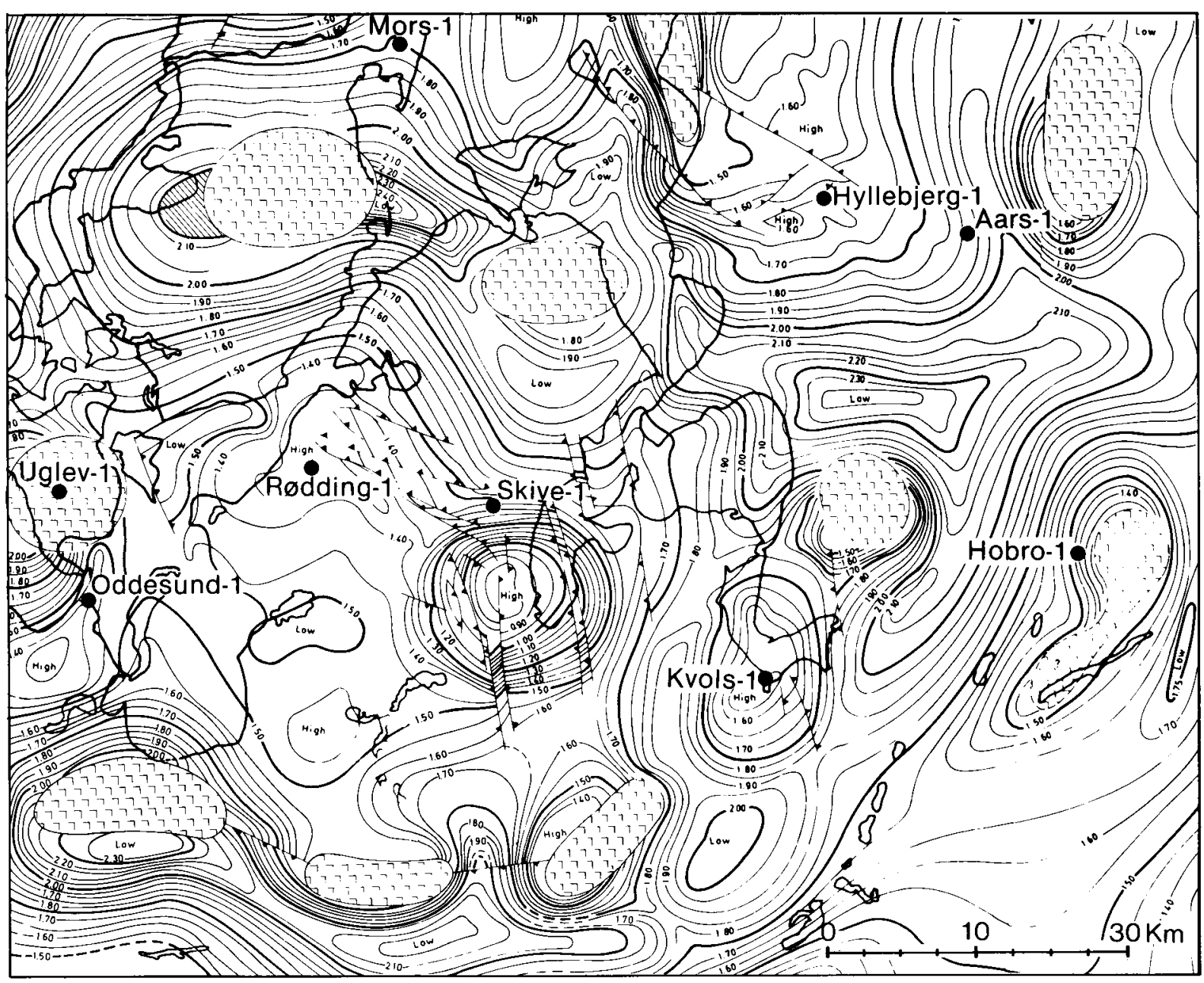

LEGEND:
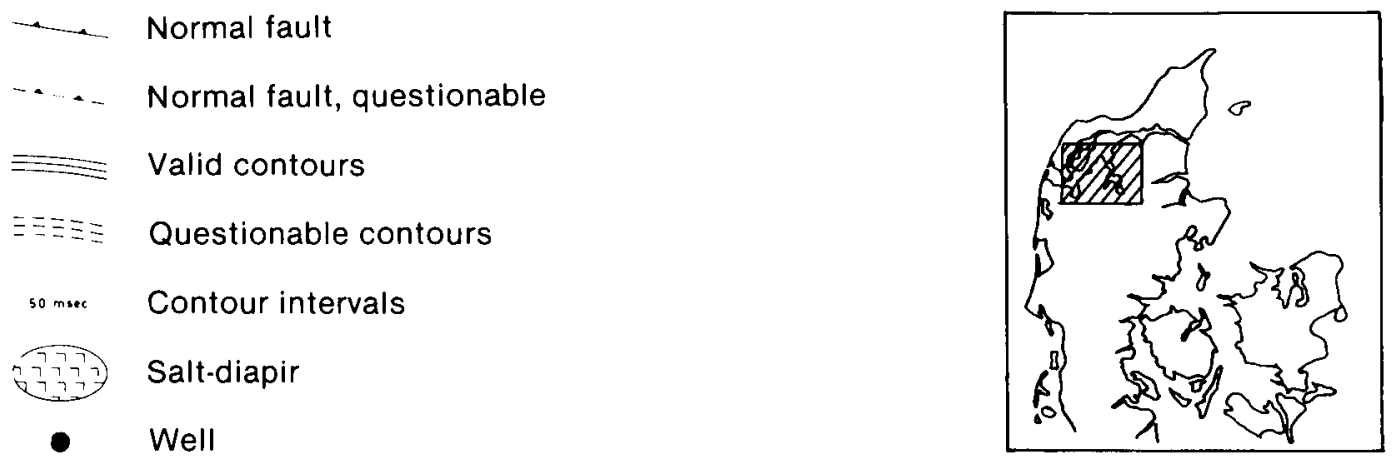

INTERPRETATION BY

J.C. BAARTMAN J.C. OLSEN D. WOODWARD

$1979-80$

Fig. 3: Seismic structural map of the top Gassum Formation in the central part of the Danish Subbasin. From Michelsen et al. (1981, p1.9). 
contemporaneously with deposition of the sequence from the F-Ib member to the Børglum Formation. Seismic data indicate that the Fjerritslev Formation is clearly truncated on the top of the salt pillow and onlapped by the Haldager Sand Formation and probably also by the Børglum Formation.

The Oddesund-1 and Rødding-1 wells were drilled more marginally in the basin, outside the Jurassic depo- centre, in an area between salt structures. The Oddesund-1 well was drilled in the primary rim-syncline of a salt diapir; seismic data show that the Jurassic sequence thins slightly towards the structure. The Rødding- 1 well is located outside the rim-synclines, but the Zechstein sequence is very thin, probably due to withdrawal of the salt. 


\section{Well descriptions}

In this section Jurassic formations drilled in the five wells, Hyllebjerg-1, Kvols-1, Oddesund-1, Rødding-1, and Skive-1, are described. The depths of the lithostratigraphic boundaries were determined from the gamma ray and sonic velocity logs (scale 1:200). Unless stated otherwise, all depths are in metres below MSL. Depths in metres below kelly bushing (KB) are presented for the lithostratigraphic boundaries in figs. 4 and 5 to allow verification by the original log data. Since the cuttings samples are labelled with depths in feet below $\mathrm{KB}$, these depth figures are used in the biostratigraphic discussion.

\section{Hyllebjerg-1}

Locality: $56^{\circ} 48^{\prime} 53^{\prime \prime} \mathrm{N}, 09^{\circ} 20^{\prime} 54^{\prime \prime} \mathrm{E}$.

Elevation: Ground $+21.1 \mathrm{~m}, \mathrm{~KB}+28.1 \mathrm{~m}$.

\section{Lithology and lithostratigraphy:}

Fjerritslev Formation, 1894-2554 m (figs. 4 and 5):

2474-2554 m (F-Ia member): Claystone, shaly, olive black, non-calcareous, with mica and traces of microlignite. Includes slightly silty layers, and highly calcareous layers (determined from the density-neutron logs).

2265-2474 m (F-Ib member): Claystone, shaly, dark grey to greyish black, slightly calcareous to calcareous, with mica and microlignite, and pyritic in places. Lowermost interbedded with silty claystone.

2177-2265 m (F-II member): Claystone, silty, in places sandy, olive black, calcareous, with mica and microlignite; locally pyritic, and glauconitic in uppermost levels.

1949-2177 m (F-III member): Claystone, shaly, greyish black to olive black, calcareous to slightly calcareous in uppermost beds, with mica, pyrite and microlignite. Yellow-coloured discoid particles (algae?) occur in the middle of the sequence, and bivalve shell fragments are present in one sidewall core from the upper levels.

1894-1949 m (F-IV member): Claystone, silty, with laminae of silt, olive black, calcareous to non-calcareous, strongly micaceous, and with traces of pyrite. The presence of carbonate cemented layers is indicated by the density-neutron logs.
Haldager Sand Formation, 1885-1894 m.

Sandstone, fine-grained, and siltstone, coarse-grained, well-sorted, light olive grey, non-calcareous, slightly micaceous, and in places containing thin laminae rich in microlignite.

\section{Flyvbjerg Formation, 1866-1885 m.}

Claystone, slightly shaly, silty, non-calcareous to slightly calcareous, with mica, microlignite and pyrite. Glauconite is present in one sidewall core. The neutron-density logs indicate the occurrence of several 0.5 $\mathrm{m}$ thick beds of siltstone and limestone in the upper part of the sequence.

Børglum Formation, 1810-1866 m.

Claystone, slightly shaly, occasionally slightly silty, dark grey to olive black, non-calcareous to slightly calcareous, with mica, microlignite, pyrite, and macrofossil shell fragments.

Frederikshavn Formation, 1663-1810 m.

Siltstone, coarse-grained, interbedded with siltstone, argillaceous, and sandstone, fine-grained, olive black, calcareous. Glauconite is recognized $\ln$ the upper and lower parts, microlignite and macrofossils in the lower part. Based on the petrophysical measurements the sequence is regarded as having a cyclic character with two clay dominated intervals, and with the two lower cycles forming coarsening-upwards sequences. The formation can be subdivided into the cycles $\mathrm{A}, \mathrm{B}$, and $\mathrm{C}$ (figs. 4 and 5, and Michelsen 1978).

\section{Chronostratigraphy:}

Ostracod analyses have been carried out through the entire sequence, generally at intervals of 30 feet. In accordance with Michelsen et al. (1984) the following subdivision is presented:

1736-1885 m: Upper Jurassic

1885-1894 m: Middle Jurassic

1894-2554 m: Lower Jurassic 
Lower Jurassic: The Fjerritslev Formation is referred to the Lower Jurassic on the basis of the ostracod faunas and correlation with neighbouring wells described by Michelsen (1975 and 1978). Ostracods found in samples from the upper part of the underlying Gassum Formation are probably the result of caving. The Gassum Formation is regarded as of Late Triassic age. The most important ostracod species are included in the range chart in Michelsen (in press, pl. 1).

In the F-Ia member and the lower F-Ib member, the fauna is characterized by Ogmoconchella aspinata, $O g$ moconcha hagenowi, Kinkelinella (K.) medioreticulata, Nanacythere (G.) elegans, $N$. (G.) circumcostata, and $N$. (G.) paracostata; this fauna is representative of the $O$. aspinata Zone and refers the sequence to the Hettangian - Lower Sinemurian.

Progonoidea reticulata occurs in the cuttings sample at $8070 \mathrm{ft}$. b.KB, referring that level to the lower Upper Sinemurian. The boundary between the Lower and Upper Sinemurian is located at the top of the $O$. aspinata Zone, at $2455 \mathrm{~m}$ (see Michelsen in press, pl. 1).

The occurrence of Ogmoconchella danica, Kinkelinella (K.) triebeli, $K$. (K.) variabilis, and $K$. (K.) laqueata in the sample interval 7680 to $7950 \mathrm{ft}$. b.KB indicates the presence of the middle subzone of the $O$. danica Zone within the F-Ib member, and refers the sequence to the Upper Sinemurian. The upper boundary of the Upper Sinemurian is located at the uppermost occurrence of $K$. (K.) variabilis, at a depth of $2306 \mathrm{~m}$.

The upper part of the F-Ib member yields species such as Pleurifera harpa, Kinkelinella (K.) foveolata, and Nanacythere? bachi, indicating the presence of the $G$. apostolescui $-K$. (K.) foveolata Subzone, and referring the sequence above $2306 \mathrm{~m}$ to the Lower Pliensbachian. The top of this subzone, corresponding to the Lower-Upper Pliensbachian boundary, is located at $2226 \mathrm{~m}$ on the basis of the uppermost occurrence of "Ogmoconchella mouhersensis«.

The ostracod fauna found in the upper part of the F-II member and in the lower part of the F-III member (up to $2070 \mathrm{~m}, 6900 \mathrm{ft}$. b. KB) is characterized by the species Ogmoconcha amalthei, $O$. contractula, Ogmoconchella adenticulata, O. bispinosa, O. pseudospina, Nanacythere (N.) firma, and $N$. (N.) simplex; this assemblage of species is indicative of the $O$. adenticulata $-N$. (N.) simplex Zone and refers the sequence 2070$2226 \mathrm{~m}$ to the Upper Pliensbachian.

The upper part of the F-III member and the F-IV member is almost barren of ostracods, as noticed elsewhere at this level (Michelsen 1975). The scattered occurrences of Pseudomacrocypris subaequabilis (see Michelsen in press, pl. 1) may be due to caving from the F-IV member, in which this species is known to be present in a few well sections (Michelsen 1975). A single specimen of Ogmoconchella sp. 4420 n.sp. was recorded in the cuttings sample from $6600 \mathrm{ft}$. b.KB; this genus was previously unknown in the upper F-III member. None of the ostracods present are of stratigraphic significance, however, so the upper part of the F-III member and the F-IV member are referred to the Toarcian, in accordance with previous work (cf. Michelsen 1975 and 1978, Michelsen et al. 1984).

The thickness of the Fjerritslev Formation exceeds that normally found in the Danish Subbasin. As the Hyllebjerg-1 well is located in an area that was not directly influenced by halokinesis, the sedimentation history at this locality may be regarded as typical of the regional basin development.

Middle Jurassic: There are no biostratigraphic data indicating the presence of the Middle Jurassic in the Hyllebjerg-1 well. However, the Haldager Sand Formation is regarded as belonging to the Bajocian-Bathonian (cf. Michelsen et al. 1984).

Upper Jurassic: The ostracod faunas from the Flyvbjerg Formation, the Børglum Formation, and, in particular, the Frederikshavn Formation show generally low densities and diversities.

The presence of Galliaecytheridea spinosa, G. elongata, Mandelstamia (maculata?), M. (rectilinea?), and Macrodentina gallica indicates Oxfordian (?) and Kimmeridgian ages for the Flyvbjerg and Børglum Formations respectively (cf. Christensen \& Kilenyi 1970). The uppermost reliable biostratigraphic indication of a Jurassic age occurs in the cuttings sample from $5930 \mathrm{ft}$. b.KB (1751 m).

The upper boundary of the Jurassic is placed at 1736 $\mathrm{m}(1764 \mathrm{~m} \mathrm{~b}$. KB) at the boundary between cycle B and $\mathrm{C}$; this is defined by correlation to the Haldager-1 well where the biostratigraphy is based on dinocysts (Davey 1982).

The overlying part of the Frederikshavn Formation (cycle C) is referred to the Lower Cretaceous.

\section{Kvols-1 \\ Locality: $56^{\circ} 31^{\prime} 49^{\prime \prime} \mathrm{N}, 09^{\circ} 17^{\prime} 56^{\prime \prime} \mathrm{E}$. \\ Elevation: Ground $+12.4 \mathrm{~m}, \mathrm{~KB}+19.2 \mathrm{~m}$.}

Lithostratigraphy and lithology (fig. 5):

Fjerritslev Formation, 1955-2405 m.

2326.3-2405 m (F-Ia member): Claystone, shaly, locally silty, dark grey to olive black, slightly calcareous, with mica and microlignite. Interbedded with thin layers of siltstone, argillaceous, weakly laminated, dark grey to greenish dark grey, calcareous, with mica, pyrite and traces of microlignite.

2177-2326.3 m (F-Ib member): Claystone, shaly, 
dark grey to greyish black, slightly calcareous, with mica and microlignite.

2164-2177 m (F-II member): Claystone, sandy, olive to brownish black, calcareous, with mica and traces of microlignite.

1973-2164 m (F-III member): Claystone, shaly to slightly shaly, generally olive grey to dark grey, locally slightly silty, slightly calcareous to non-calcareous, with mica and microlignite. Pyrite and yellow coloured discoid particles (algae?) occur locally in the upper levels.

1955-1973 m (F-IV member): Claystone, silty, slightly shaly, calcareous, with mica and traces of pyrite and microlignite. Laminae of medium- to coarsegrained siltstone are observed.

Haldager Sand Formation, 1940-1955 m.

Sandstone, medium- to coarse-grained, interbedded with fine-grained sandstone, moderately to poorly sorted, locally argillaceous, slightly calcareous to noncalcareous. Thin layers of claystone, very sandy, noncalcareous. The formation coarsens upwards.

Flyvbjerg Formation is absent.

Børglum Formation, 1912-1940 m.

Claystone, slightly sandy in lowermost levels, olive grey to black, slightly calcareous, micaceous.

Frederikshavn Formation, 1856-1912 m.

Siltstone, medium- to coarse-grained, argillaceous, olive grey, non-calcareous, with glauconite and traces of mica and pyrite. Interbedded with claystone, silty, greyish black, calcareous, with mica and microlignite. Two coarsening upwards sequences occur in the lower part of the formation, probably corresponding to cycles A and B (sensu Michelsen 1978). Thus, the interval corresponding to cycle $\mathrm{C}$ seems dominated by clay in this well section.

\section{Chronostratigraphy:}

Biostratigraphic analyses have only been carried out in the upper part of the Fjerritslev Formation. Thus, the subdivision presented below is based mainly on correlation of the lithostratigraphic units with those in the Hyllebjerg-1, Hobro-1, Oddesund-1, Rødding-1, and Voldum-1 wells (Michelsen 1979).

In accordance with Michelsen et al. (1984) the drilled section may be subdivided as follows:

1922-1940 m: Upper Jurassic

1940-1955 m: Middle Jurassic

1955-2405 m: Lower Jurassic
The Gassum Formation, underlying the Fjerritslev Formation, is considered to be of Late Triassic age.

Lower Jurassic: The log-motifs of the F-Ia and F-Ib members seem fully developed when compared to the Hyllebjerg-1 well although the thickness of the latter member is slightly reduced, probably condensed (Michelsen, in press). The F-II member is incomplete, in that the upper and lower units are missing, and the sequence may contain hiati (fig. 5). Biostratigraphic evidence is generally poor. One sample within the F-II member contains only the ostracod species Ogmoconchella aegualis, indicating a Late Pliensbachian age. A further sample at the lower boundary of the member (7210 ft. b.KB) yielded the species Pseudomacrocypris subtriangularis and Kinkelinella sp. suggesting an age not younger than the Early Pliensbachian.

The F-III member is reduced in thickness compared to the same sequence in the Hyllebjerg-I well. Correlation based on the log-motifs makes it obvious, however, that the lower half of the member is complete (Michelsen in press, fig. 2). Analyses of the ostracods indicate a fauna characterized by Ogmoconcha contractula, $\mathrm{O}$. amalthei, Ogmoconchella adenticulata, and $\mathrm{Na}$ nacythere (N.) simplex. The uppermost occurrence of the fauna is in the cuttings sample from $6790 \mathrm{ft}$. b.KB. The species Ogmoconchella transversa, which is known from the lower part of the Upper Pliensbachian, is only found below $7060 \mathrm{ft}$. b.KB. The fauna described above is indicative of the $O$. adenticulata $-N$. (N.) simplex Zone and refers the sequence $2047-2172 \mathrm{~m}$ to the Upper Pliensbachian. The uppermost part of the F-III member, 1973-2047 m, is barren of ostracods and may be of Toarcian age (cf. Michelsen 1975 and 1978). Compared to the corresponding sequence in the Hyllebjerg-1 well, 1949-2070 m, the sequence in the Kvols well is reduced in thickness.

The uppermost part of the formation, the F.IV member, is clearly relatively thin, and compared to the Hyllebjerg-1 well the upper half of the member is missing. Based on regional considerations this may be explained by erosion accompanying Middle Jurassic (Mid Cimmerian) uplift.

Middle Jurassic: It is represented by the Haldager Sand Formation, which is of expected thickness for this part of the Danish Subbasin.

Upper Jurassic: Since the Flyvbjerg Formation is missing it is assumed that only the uppermost Oxfordian is represented by the basal part of the Børglum Formation. The log-motifs of the Børglum and Frederikshavn Formations indicate that no significant intervals of these formations are missing but they are condensed in comparison to the Hyllebjerg section. Until biostratigraphic analyses have been carried out it must be assumed that strata of Kimmeridgian and Volgian age 
are present, whereas at least the lower part of the Oxfordian is missing.

\section{Oddesund-1}

Locality: $56^{\circ} 33^{\prime} 36^{\prime \prime} \mathrm{N}, 08^{\circ} 34^{\prime} 10^{\prime \prime} \mathrm{E}$.

Elevation: Ground $+2.45 \mathrm{~m}, \mathrm{~KB}+9.15 \mathrm{~m}$.

Lithostratigraphy and lithology (fig. 5):

Fjerritslev Formation, 1608-1894 m.

1810-1894 m (F-Ia member): Claystone, shaly, slightly silty to silty, dark grey to olive black, slightly to very calcareous, with silty layers and/or carbonate cemented layers in the upper part of the member.

1661-1810 m (F-Ib member): Claystone, shaly, dark grey to greyish black, calcareous to slightly calcareous (decreasing upwards), with mica and traces of microlignite and pyrite, the latter often delineating trace fossils.

1608-1661 m (F-II member): Lowermost claystone slightly shaly, olive grey, calcareous, locally pyritic. Overlain by a heterogeneous series comprising claystone, sandy to very sandy, light olive grey to olive black, non-calcareous, with pyrite, mica and microlignite, interbedded with sandstone, fine-grained, moderately sorted, and siltstone, medium- to coarse-grained, sandy, dark yellowish brown, non-calcareous.

\section{Haldager Sand Formation, 1604-1608 m.}

Sandstone, fine-grained, slightly silty, olive grey, calcareous, with traces of pyrite.

Flyvbjerg Formation, 1601-1604 m.

Claystone, shaly, dark grey, calcareous, with mica and microlignite, and traces of pyrite. The silt content increases upwards.

Børglum Formation, 1556-1601 m.

Claystone, slightly silty, slightly shaly, olive black, noncalcareous, with mica, microlignite and pyrite.

Frederikshavn Formation, 1487-1556 m.

Claystone, slightly to very silty, dark yellowish brown, non-calcareous, with traces of mica, microlignite and pyrite. Interbedded with siltstone, medium- to coarsegrained, olive black, moderately sorted, non-calcareous, locally with glauconite, microlignite, and traces of mica. The formation is tentatively subdivided into the cycles A, B, and C (fig. 5), although the log-motifs do not show the coarsening upwards trends as described form the Hyllebjerg-1 well section.

\section{Chronostratigraphy:}

Ostracod analyses were carried out in selected samples, primarily to determine the age of the F-II member and the Børglum Formation. Therefore, the chronostratigraphic subdivision is primarily based on correlation of the lithostratigraphic units with the Hyllebjerg-1 well, resulting in the following subdivision:

1517-1604 m: Upper Jurassic

1604-1608 m: Middle Jurassic

1608-1894 m: Lower Jurassic

The sequence below $1894 \mathrm{~m}$ is referred to the Gassum Formation, which is regarded to be of Late Triassic age.

The sequence above $1517 \mathrm{~m}$, the upper cycle of the Frederikshavn Formation, is referred to the Lower Cretaceous.

Lower Jurassic: The Fjerritslev Formation is referred to the Lower Jurassic.

Within the F-Ia member one sample has been analysed (6070 ft. b.KB.). The ostracod fauna is dominated by Ogmoconchella aspinata, Kinkelinella $(K$. medioreticulata, and Ogmoconcha hagenowi, which together with the occurrence of Nannacythere (G.) elegans refer this horizon to the latest Hettangian or Early Sinemurian.

Within the F-Ib member three samples (5530 ft., $5660 \mathrm{ft}$. and $5820 \mathrm{ft}$. b.KB) were analysed. The lower sample contains a sparse ostracod fauna characterized by Kinkelinella $(K$.) triebeli and Progonoidea reticulata referring the fauna to the $P$. reticulata Subzone and the horizon to the lowermost Upper Sinemurian. As this subzone is rather thin elsewhere in the subbasin, the Lower-Upper Sinemurian boundary is expected to be located closely below this sample. The middle sample contains a sparse ostracod fauna known from Upper Sinemurian. The upper sample is dominated by $O g$ moconchella pseudospina, O. bispinosa, O. transversa, "O. mouhersensis", Ogmoconcha amalthei, and Kinkelinella $(K$.) foveolata, a fauna that is strongly indicative of the Lower Pliensbachian. However, Kinkelinella $(K$.$) variabilis, which occurs in the same sample, is$ typical of the Upper Sinemurian. The conclusion must be that the Sinemurian-Pliensbachian boundary occurs near the top in the F-Ib member in this well section. The abundance of Pliensbachian faunal elements in the cuttings sample at $5530 \mathrm{ft}$. b.KB probably results from caving.

From the F-II member, three cuttings samples (5360 ft., $5390 \mathrm{ft}$. and $5430 \mathrm{ft}$. b.KB) and one sidewall core (5367 ft. b.KB) were analysed. The lower sample yielded a relatively rich ostracod fauna, characterized by Nanacythere? bachi, Ogmoconchella pseudospina, and Ogmoconchella adenticulata, indicating the presence of Lower Pliensbachian strata. The ostracod fau- 
nas in the two samples from $5367 \mathrm{ft}$. and $5390 \mathrm{ft}$. b.KB are less abundant and are characterized by Acrocythere tricostata (sensu Michelsen 1975), Liasina vestibulifera, and Ogmoconchella pseudospina, indicating a Late Pliensbachian age for this stratigraphic interval. In the upper sample ( $5360 \mathrm{ft} . \mathrm{b} . \mathrm{KB}$ ) the occurrence of a specimen of Ogmoconchella sp. is indicative only of an Early Jurassic age. The Lower-Upper Pliensbachian boundary must lie within the interval $5390-5430 \mathrm{ft}$. b.KB, e.g. close to a depth of $1640 \mathrm{~m}$.

The log-motifs and the thickness of the F-Ia member are closely comparable to those of the Hyllebjerg section, whereas the F-Ib member seems slightly condensed. This suggests that no hiati are present within the Hettangian and Sinemurian interval. In the F-II member, all three lithostratigraphic subunits are recognized. The log-motifs and thicknesses of these subunits are comparable with those of the Hyllebjerg section. The F-III and F-IV members are missing. This lithostratigraphic subdivision and the biostratigraphic analyses indicate the presence of Lower Pliensbachian and (?) lower Upper Pliensbachian strata, whereas the upper part of the Upper Pliensbachian and the Toarcian are not represented.

Middle Jurassic: The Haldager Sand Formation is referred to the Middle Jurassic purely on lithostratigraphic grounds. The sequence is very thin compared to other well sections.

Upper Jurassic: The occurrence of the Flyvbjerg Formation is suggestive of the Oxfordian stage (see Michelsen 1978). A sample from the uppermost Fjerritslev Formation (5320 ft. b.KB), yielded an ostracod fauna with Oxfordian affinities. This fauna may have been derived from the Flyvbjerg Formation due to caving. The Flyvbjerg Formation is unusually thin in this well.

The overlying Børglum and Frederikshavn Formations both show thicknesses comparable to those observed in the Rødding-1, Skive-1, and Kvols-1 wells. The thicknesses are reduced relative to the Hyllebjerg-1 well, but the log-motifs are closely correlatable so that the sequences are probably condensed rather than containing discrete hiati. Four samples (5000, 5100,5190 , and $5250 \mathrm{ft}$. b.KB) were examined for ostracods. All four samples contain faunas that refer the sequence to the Upper Jurassic. The species Galleocytheridea teres, G. spinosa (?), G. punctata, and Mandelstamia spp. were recorded from the lowermost two samples, thus referring the Børglum Formation to the Kimmeridgian.

The Frederikshavn Formation is tentatively subdivided into the three cycles known from Hyllebjerg-1. The Jurassic-Cretaceous boundary is located at the B-C cycle boundary, at a depth of $1517 \mathrm{~m}$.

\section{Rødding-1}

Locality: $56^{\circ} 38^{\prime} 49^{\prime \prime} \mathrm{N}, 08^{\circ} 48^{\prime} 18^{\prime \prime} \mathrm{E}$.

Elevation: Ground $+24.7 \mathrm{~m}, \mathrm{~KB}+31.4 \mathrm{~m}$.

Lithostratigraphy and lithology (fig. 5):

Fjerritslev Formation, 1647-1916 m.

1852.1-1916 m (F-Ia member): Claystone, shaly, in places silty, greyish black to olive black, calcareous, with mica, microlignite, and pyrite. Interbedded with thin highly calcareous layers.

1712-1852.1 m (F-Ib member): Claystone, shaly, in places slightly silty, dark grey to olive black, calcareous to non-calcareous, with mica and microlignite, and traces of pyrite. Increasing silt content in uppermost levels, where interbedded with siltstone, argillaceous, greyish black, calcareous.

1676-1712 m (F-II member): Claystone, silty to sandy and siltstone, argillaceous, olive grey to black, calcareous, with mica, pyrite, and microlignite. A thin layer of dolomite was recorded in one sidewall core.

1647-1676 m (F-III member): Claystone, shaly, olive black, calcareous to slightly calcareous, with mica and microlignite.

Haldager Sand Formation is absent.

Flyvbjerg Formation, 1636-1647 m.

Sandstone in lowermost interval, fine-grained with laminae of claystone, silty, black, calcareous, with mica and microlignite; passing upwards into siltstone, calcareous, with laminae of very argillaceous siltstone, containing mica and microlignite. Uppermost levels comprise claystone, shaly, silty, olive black, slightly calcareous, with glauconite, mica and microlignite.

\section{Børglum Formation, 1596-1636 m.}

Claystone, shaly, greyish to olive black, non-calcareous, with mica and pyrite and traces of microlignite. Silty in the upper part.

Frederikshavn Formation, 1546-1596 m.

Siltstone, greenish grey, medium- to coarse-grained, non-calcareous, moderately to well sorted, containing glauconite and traces of microlignite. The siltstone is variably argillaceous and interbedded locally with claystone. A thin limestone bed was observed in a sidewall core. 


\section{Chronostratigraphy:}

Ostracod analyses were carried out in 10 cuttings samples, primarily to determine the age of the upper part of the Fjerritslev Formation.

The chronostratigraphic subdivision is generally based on correlation of the petrophysical data with the Hyllebjerg, Hobro, and Voldum wells, resulting in the following subdivision:

1576.6 (?)-1647 m: Upper Jurassic 1647-1916 m: Lower Jurassic

The Middle Jurassic is absent (see below). The sediments below $1916 \mathrm{~m}$ belong to the Gassum Formation, which is referred to the Upper Triassic.

The sequence above $1576.6 \mathrm{~m}$ (cycle $\mathrm{C}$ of the Frederikshavn Formation) is referred to the Lower Cretaceous.

Lower Jurassic: The F-Ia member is slightly condensed relative to the sequences developed in the Hyllebjerg-1, Kvols-1, and Skive-1 wells. The ostracod fauna in the cuttings sample from $6210 \mathrm{ft}$. b.KB, comprises Ogmoconchella danica, Ogmoconcha hagenowi, Kinkelinella (K.) triebeli, and Progonoidea reticulata, which indicate a Late Sinemurian age. The occurrence of these species in this part of the F-Ia member may be due to caving. The occurrence of a juvenile specimen of the Ogmoconchella aspinata in the same sample suggests an age no younger than the Early Sinemurian.

The log-motifs of the F-Ib member seem normally developed, but the thickness is slightly less than that known from the Hyllebjerg well, so the member may be slightly condensed in the Rødding- 1 well.

The F-II member is condensed compared to the Hyllebjerg sequence, but is closely comparable with the Skive sequence, except that the upper sub-unit (IIc) is absent in the Rødding-1 well. One cuttings sample (5670 ft. b.KB) yielded a sparse ostracod fauna comprising Ogmoconchella danica and Ogmoconcha amalthei, which is suggestive of an Early Pliensbachian age.

The F-III member is markedly reduced in thickness compared to the other wells. Correlation of the logmotifs with the Hyllebjerg section shows that the sequence in the Rødding-1 well corresponds to the lowermost part of the F-III member in the Hyllebjerg-1 well. Two cuttings samples (5550 and $5580 \mathrm{ft}$. b. KB) yielded an ostracod fauna including Ogmoconchella adenticulata, O. danica, O. septenaria, and Nanacythere (D.) firma referring the sequence to the Upper Pliensbachian. It is concluded that the upper part of the F-III member is absent in the Rødding-1 well. The Lower-Upper Pliensbachian boundary is assumed to occur within the F-II member.

The F-IV member is absent in the Rødding- 1 well.
Therefore, the Lower Jurassic is only represented by the Hettangian to Upper Pliensbachian in this well.

Middle Jurassic: The absence of the Haldager Sand Formation indicates that the Middle Jurassic is represented by a hiatus in the Rødding- 1 well.

Upper Jurassic: The Flyvbjerg Formation is slightly reduced in thickness compared to the Hyllebjerg section, but the presence of this formation indicates sediments of Oxfordian age.

The thickness and petrophysical characteristics of the Børglum Formation are comparable to those observed in the Hyllebjerg-1 well. The ostracod faunas from two samples, one close to the upper boundary of the formation, indicate a Late Jurassic, probably Kimmeridgian, age.

The Frederikshavn Formation is markedly thinner than in the Hyllebjerg well and does not show the characteristic log-motifs. However, the lower boundary of cycle $\mathrm{C}$ is tentatively placed at a depth of $1576.6 \mathrm{~m}$ (1608 $\mathrm{m} \mathrm{b.KB}$ ). If correct, this suggests that the absent or condensed portion of the formation must correlate with cycles A and B of the Hyllebjerg-1 section, corresponding to the uppermost part of the Upper Jurassic.

\section{Skive-1}

Locality: $56^{\circ} 37^{\prime} 38^{\prime \prime} \mathrm{N}, 09^{\circ} 00^{\prime} 11^{\prime \prime} \mathrm{E}$.

Elevation: Ground $+20.7 \mathrm{~m}, \mathrm{~KB}+28 \mathrm{~m}$.

Lithostratigraphy and lithology (fig.5):

Fjerritslev Formation, 1702-2093 m.

2015-2093 m (F-Ia member): Claystone, in places slightly silty, shaly, dark grey to brownish black, noncalcareous, with mica and pyrite, and traces of microlignite. The occurrence of a few carbonate cemented layers is indicated by petrophysical data.

1860-2015 m (F-Ib member): Claystone, in places slightly silty, shaly, dark grey, calcareous to non-calcareous, with mica, microlignite, and pyrite.

1826-1860 m (F-II member): Claystone, with increasing silt content upwards. A sidewall core uppermost in the member comprises limestone with thin laminae of clay, and fragments of macrofossils.

1702-1826 m (F-III member): Claystone, shaly, lo-

Fig. 4: The Jurassic sequence of the Hyllebjerg-1 well represented by SP, Resistivity, Gamma Ray, and Interval Transit Time ("Sonic") logs. The Hyllebjerg-1 well is the reference section of the F-Ia to F-IV members, as they are defined in the present paper. 


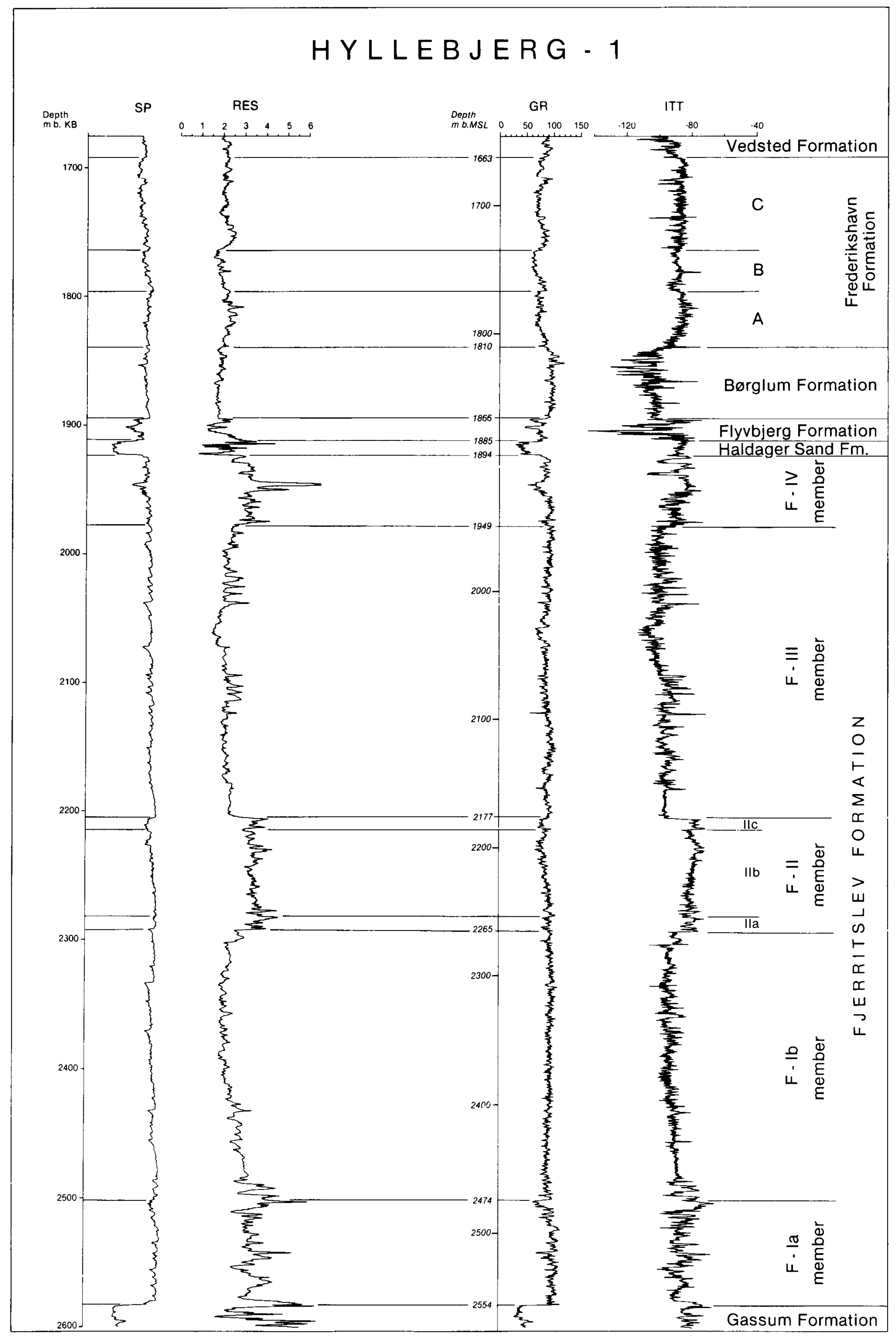


cally slightly silty, dark grey to olive black, non-calcareous to slightly calcareous, with mica and microlignite.

Haldager Sand Formation, 1690-1702 m.

Sandstone and siltstone, light olive grey, locally dark grey, slightly calcareous to non-calcareous with microlignite and coal fragments. The grain size decreases upwards from medium-grained sand to silt with clay laminae in the upper levels.

Flyvbjerg Formation, 1670-1690 m.

Thinly interbedded sequence of siltstone, sandstone, and claystone. Generally, the grain size increases upwards, and sequence capped by a layer of fine-grained sandstone, carbonate-cemented. Non-calcareous in the lower part of the sequence. Light olive grey, dark greenish grey, and greyish black. Microlignite and coal fragments occur through the entire sequence, glauconite and shell fragments in the upper part.

Børglum Formation, 1629-1670 m.

Claystone, shaly, in places slightly silty, dark grey, non-calcareous, with mica and pyrite, and traces of microlignite.

Frederikshavn Formation, 1559-1629 m.

Siltstone, coarse-grained, olive grey, non-calcareous to slightly calcareous, with glauconite, mica and pyrite. Argillaceous in basal, and uppermost levels. Interbedded with fine-grained sandstone. Based on log-correlation, the formation is subdivided into the cycles $\mathrm{A}, \mathrm{B}$, and C (sensu Michelsen 1978). Only cycle A has a coarsening upwards trend as seen in the Hyllebjerg-1 well.

\section{Chronostratigraphy:}

Biostratigraphic analyses were not carried out on the Jurassic sequence in the Skive-1 well. The chronostratigraphic subdivision outlined below is based on lithostratigraphic log correlation with the better-dated Hyllebjerg-1, Hobro-1, and Voldum-1 wells.
1588-1690 m: Upper Jurassic 1690-1702 m: Middle Jurassic 1702-2093 m: Lower Jurassic

The deposits below $2093 \mathrm{~m}$ are assigned to the Gassum Formation, which is referred to the Upper Triassic. The upper cycle of the Frederikshavn Formation, above $1588 \mathrm{~m}$, is referred to the Lower Cretaceous.

Lower Jurassic: The F-Ia member is closely comparable, both in terms of thickness and log-motifs, to the sequence in the Hyllebjerg- 1 well.

The F-Ib member is thinner than the equivalent sequence in the Hyllebjerg-1 well, but shows the same petrophysical characteristics which indicates that the sequence is complete but condensed in the Skive-1 well.

Similarly, the F-II member appears condensed even though all three subunits are present.

Analysis of the petrophysical data from the F-III member indicates a close correlation with the lower $\mathrm{c}$. $100 \mathrm{~m}$ of the member in the Hyllebjerg-1 well; this interval has a Late Pliensbachian to earliest Toarcian age in the Hyllebjerg-1 well.

The F-IV member is absent.

Middle Jurassic: The thickness of the Haldager Sand Formation is comparable with that in the Hyllebjerg-1 well.

Upper Jurassic: The development of a relatively thick Flyvbjerg Formation suggests that the Oxfordian stage is represented in this well.

The log-motifs of the Børglum and Frederikshavn Formations indicate that a complete sequence is present, although condensed relative to the Hyllebjerg-1 well. Thus, the Upper Jurassic is assumed to be essentially complete. 


\section{Lithostratigraphic discussion}

A lithostratigraphic subdivision of the Jurassic in the Danish Subbasin was first presented by Larsen (1966). He subdivided the sequence into the Fjerritslev, Haldager, Børglum and Frederikshavn Formations; this lithostratigraphic scheme was modified by Michelsen (1978). The formation boundaries were adjusted and determined by means of petrophysical measurements. The Fjerritslev Formation was subdivided into four informal members, and the Haldager Formation into the Haldager Sand and the Flyvbjerg Member. In addition, the Børglum and Frederikshavn Formations were included as members of the Bream Formation, as defined by Deegan \& Scull (1977) from the Norwegian sector of the North Sea. In their new revision of the Norwegian lithostratigraphic scheme, however, Vollset \& Doré (1984) avoided use of the Bream Formation. Consequently, the Bream Formation is no longer retained as a lithostratigraphic unit within the Danish Subbasin.

\section{Definition of the members of the Fjerritslev Formation}

The Fjerritslev Formation was formerly subdivided into four informal members and the lower member into two subunits (Michelsen 1978). These five lithostratigraphic units are similarly treated as informal members in this paper. They are easily recognized in nearly all Danish well sections. Furthermore, the F-II member is mappable over large areas on the basis of seismic data (Boldreel 1985). Since they are recognizable by their lithologic and petrophysical characteristics, and therefore mappable throughout the area where the Fjerritslev Formation is present, these members could be elevated to the rank of formations. In this event, the Fjerritslev Formation would be raised to group status, corresponding to the time-equivalent Dunlin Group (cf. Vollset \& Doré 1984). However, the Fjerritslev Formation has been known for 23 years and the informal members for 11 years, and the names are in conventional use. To introduce a new rank for the formation and new formal names for the present members would probably cause unnecessary confusion and would not substantially simplify future work on the Lower Jurassic sequence.

The descriptions of the five well sections given above do not add significant new lithological information to the earlier work of Michelsen (1978). However, the combination of cuttings samples, sidewall cores and modern petrophysical data from these wells provides a better lithostratigraphic database than was previously available. Furthermore, the Hyllebjerg-1 well is located in a substantial distance from discrete salt structures, yet is still within the salt structure province of the Danish Subbasin. The Hyllebjerg-1 well may thus be regarded as the most representative section in terms of the lithology and thickness of the Jurassic formations in the basin. The Hyllebjerg-1 well is, therefore, proposed as a reference section of the Fjerritslev Formation that displays the subdivision into 5 informal members.

F-Ia member: Hyllebjerg-1, 2474-2554 m. The F-Ia member consists of claystone interbedded with siltstone and limestone (or carbonate-cemented siltstone) layers. This member probably represents the Early Jurassic transgressive stage (Michelsen 1978, Pedersen 1986). The uppermost part of the member is assumed to be time-equivalent with the interfingering of the Gassum and Fjerritslev Formations in the Vedsted-1 well (Michelsen 1978). The log-motifs and thicknesses of the F-Ia member are nearly identical in the five wells, and can be correlated in detail to most well sections in northern Jylland (figs. 4-5).

F-Ib member: Hyllebjerg-1, 2265-2474 m. The F-Ib member is dominated by claystone as indicated by the gamma ray readings. Thicknesses and log-motifs of this member vary very little from well to well in northern Jylland. Close examination of the log-motifs in the five well sections indicates that subdivision of the member and detailed correlation of log-motifs are possible. Such detailed recognition and correlation of log-motifs allows differentiation between a condensed sequence and a sequence with discrete hiati (see Michelsen in press).

F-II member: Hyllebjerg-1, 2177-2265 m. This member differs from the sequences above and below in that it consists of faintly laminated claystones with a relatively high silt and sand content (Michelsen 1978). Furthermore, it is clearly distinguished from the sequences above and below by the log-motifs (see fig. 5).

The characteristic features of the F-II member in the Hyllebjerg-1 well are similar to those observed in the 
Fjerritslev-2 and J-1 wells (cf. Michelsen 1978, figs. 5 and 6). In all three well sections the member can be subdivided into three well-defined subunits, which have proved of importance in regional lithostratigraphic correlation. This tripartite subdivision is not recognized in wells situated to the southeast, such as the Hobro-1, Voldum-1, and Rønde-1 wells (see Michelsen 1979 , plate 4 ).

The log-motifs of the Hyllebjerg- 1 section are correlatable with the Oddesund-1, Rødding-1, and Skive-1 sections, though the uppermost subunit is not recognized in the Oddesund and Rødding- 1 wells. The sequence encountered in the Kvols- 1 well is assumed to represent only the middle subunit. The gamma ray log-motifs within the Oddesund-1 and Rødding-1 sections show larger deflections than observed in the Hyllebjerg-1, and the sidewall cores indicate the presence of increased coarse clastic sediments in these two well sections. Halokinetic movements during the transition Early-Late Pliensbachian time may explain these differences in thickness and also the missing tripartite subdivision in wells, such as Kvols-1 and Rødding- 1 . However, the presence of hiati has not yet been proved by any other method; the resolution of the biostratigraphic and seismic stratigraphic methods applied to this area is not sufficiently detailed.

F-III member: Hyllebjerg-1, 1949-2177 m. The F-III member is dominated by claystone, which in places is slightly silty. The member is present in the Rødding- 1 , Skive-1, Kvols-1 and Hyllebjerg-1 wells, but its thickness is highly variable. The log-motifs of the member in the Rødding-1 and Skive-1 wells correlate with the lower part of the F-III member in Hyllebjerg-1 (Michelsen in press, fig. 2). This log-stratigraphic correlation is supported by the ostracod biostratigraphy from the Rødding-1 well (fig. 5). Since the F-III member in Rødding-1 and Skive-1 is overlain by the Flyvbjerg Formation and the Haldager Sand Formation, respectively, erosion of the Fjerritslev Formation is assumed to have taken place during the earliest Middle Jurassic (see also Michelsen 1978).

The log-motifs of the majority of the member in the Kvols-1 well correlate closely with the lower half of the sequence in Hyllebjerg-1 (Michelsen in press, fig. 3). This correlation is supported by the above-mentioned biostratigraphic data. Hence, the thinned interval in Kvols-1 must be represented in the upper part of the member. As this upper part is barren of ostracods, it is not yet possible to prove the presence of hiati in this well section. The presence of the F-IV member, however, suggests that a reduced sedimentation rate in the Kvols area may best explain the differences between the Kvols-1 and Hyllebjerg-1 sequences.

F-IV member: Hyllebjerg-1, 1894-1949 m. The F-IV member consists of claystone with varying silt content, interbedded with sandstone and carbonate-cemented sandstone. The sequence encountered in Hyllebjerg-1 correlates closely with the sequences in the J-1, Fjerritslev-1, and Haldager-1 wells (see Michelsen 1978, figs. 5,6 , and 15). The log-motifs indicate the presence of two significantly coarser (probably carbonate cemented) clastic units.

The sequence observed in the Kvols-1 well is interpreted to represent the lower of these two sedimentary cycles.

\section{Haldager Formation (abandoned)}

This lithostratigraphic term was introduced by Larsen (1966) to refer to the Dogger sequence. Michelsen (1978) redescribed the formation and defined it as a sand-dominated sequence of Middle Jurassic to $\mathrm{Ox}$ fordian age. The formation was subdivided into two members: the Haldager Sand and the Flyvbjerg Member. A recent evaluation of the environment was published by Koch (1983). Renewed and mainly unpublished biostratigraphic investigations, carried out within the last decade by the Geological Survey of Denmark and private companies, have clearly shown that there is a regional hiatus between the two members. The Haldager Sand seems to be of Bajocian to Bathonian age whereas the Flyvbjerg Member is of Oxfordian to earliest Kimmeridgian age, i.e. deposits of Callovian age are not proven (pers. comm. Niels Poulsen 1988, see also Michelsen et al. 1984).

According to the rules presented by Hedberg (1976) a sedimentary series that straddles a regional hiatus cannot be included into one formation. Therefore, the present author suggests that the term Haldager Formation be abandoned, and that the two members be elevated to the rank of formations. In the present paper they are named the Haldager Sand Formation and the Flyvbjerg Formation, respectively. As introduction of new geographic names would contribute to confusion in the stratigraphic literature, the name Haldager is retained, together with the indication of lithology. For the lithostratigraphic definition the reader is referred to Michelsen (1978, pp. 16-19).

Fig. 5: Lithostratigraphic subdivision of the Jurassic sequence in the Hyllebjerg-1, Kvols-1, Oddesund-1, Rødding-1, and Skive-1 wells. The Frederikshavn Formation is subdivided into cycles $A, B$, and $C$ in accordance with Michelsen (1978). Note that the chronostratigraphy, based on biostratigraphic analyses, is indicated to the right of the well profiles. Single triangular symbols represent the location of individual biostratigraphic samples. A vertical line represents a continuous series of samples, and the triangular symbol marks the top of the chronostratigraphic unit or biozone. 


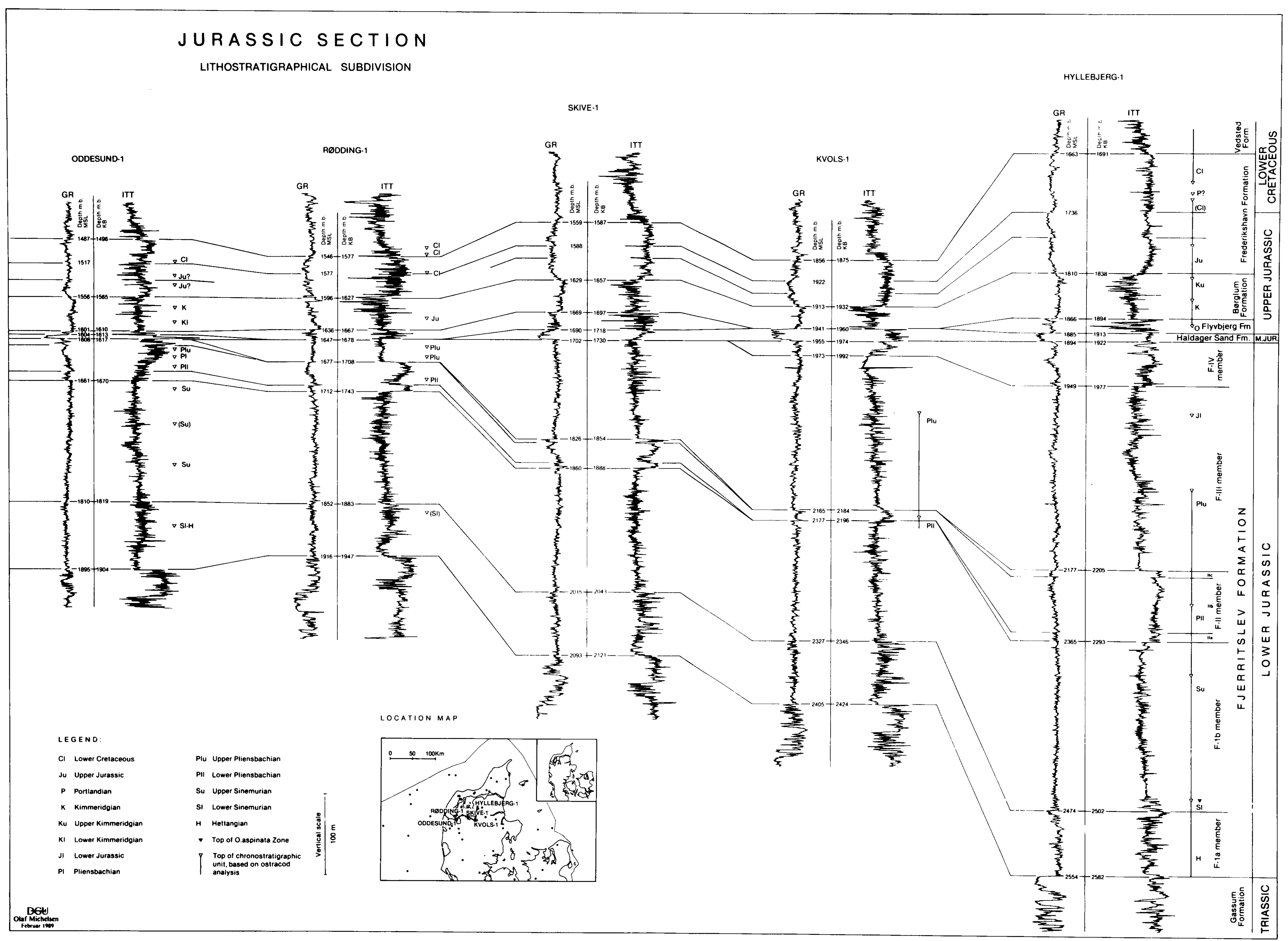




\section{Haldager Sand Formation (new rank)}

The formation is present in four of the five wells. In the Hyllebjerg-1 and Kvols-1 wells the sequence generally coarsens upwards, but in the Oddesund-1 and Skive-1 wells the formation is represented by a fining upward sequence. The correlation of these sequences is based on their overall coarse-grained nature which is compatible with the type section of the formation in the Haldager-1 well.

\section{Flyvbjerg Formation (new rank)}

This formation is present in four of the five wells, and shows significant variations in thickness (see fig. 5). In the Kvols-1 well, the Børglum Formation directly overlies the Haldager Sand Formation.

In the four wells the sequence is generally coarsening upwards, with claystone dominating the lowermost interval and silt- or sandstone the uppermost levels. The occurrence of a thin limestone layer near the top of the formation in the Hyllebjerg-1 well was determined from petrophysical data. The nature of both the logmotifs and the lithology are closely comparable to those of the type section, Flyvbjerg-1 well, and the reference section, Haldager-1 well (see Michelsen 1978, fig. 8). However, the thicknesses of the formation in these four wells are between a half or a third of that recorded from the type and reference sections.

\section{Bream Formation (abandoned)}

The Bream Formation was defined by Deegan \& Scull (1977) but recently was avoided by Vollset \& Doré
(1984); the latter authors suggested furthermore that the Børglum Member should be elevated to the rank of formation. Vollset \& Doré (1984) stated that the Frederikshavn Member is not present in the Norwegian North Sea sector, which is in accordance with the reinterpretation given by Michelsen et al. (1984) and discussed below.

As the Bream Formation was introduced into the Danish Subbasin from the Norwegian part of the Norwegian-Danish Basin, this lithostratigraphic term is here abandoned. The corresponding sequence will be renamed as the Børglum and Frederikshavn Formations.

\section{Børglum Formation (new rank)}

The formation is present in all five wells. With the exception of the gamma ray log in the Rødding- 1 well, the log-motifs possess similar characteristics to those described by Michelsen (1978). Based on the log-motifs, it can be concluded that the formation lacks significant hiati, although the thickness is variable in these well sections. The resistivity and SP logs from the Hyllebjerg-1 well (fig. 4) correlate closely with those of the type section in the Børglum-1 well (cf. Michelsen 1978, fig. 10).

\section{Frederikshavn Formation (new rank)}

The formation is present in all five wells. It is significantly thicker in the Hyllebjerg-1 well than in the other four wells, probably because this well is situated centrally in the basin and is not influenced by halokinetic structures.

\section{MIDDLE JURASSIC - LOWER CRETACEOUS LITHOSTRATIGRAPHIC CORRELATION CHART}

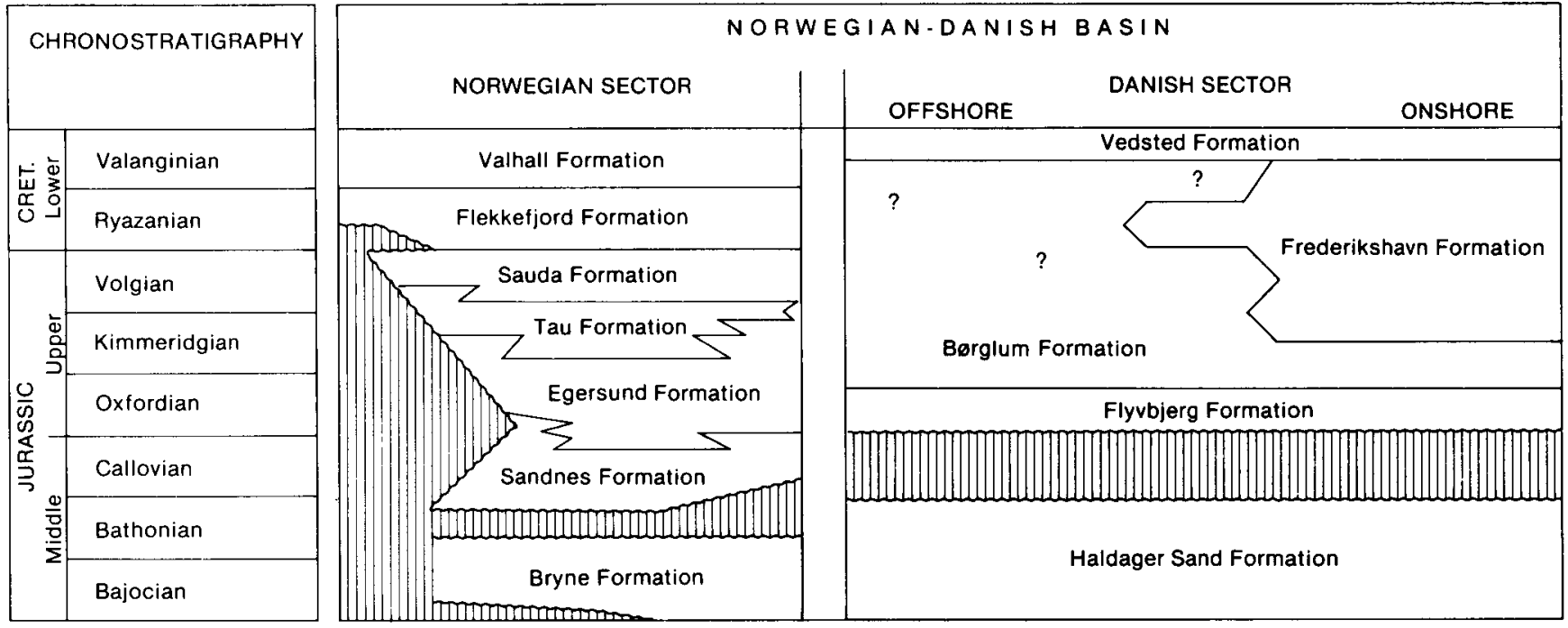

Fig. 6: Correlation chart of the Middle Jurassic to Lower Cretaceous formations in the Norwegian-Danish Basin. The formations from the Norwegian sector are defined in Vollset \& Doré (1984). 
The Frederikshavn Formation in the five wells is finer grained than in the type section (Frederikshavn-1 well), but it is still readily differentiated from the finegrained formations above and below. In the Børglum-1, Frederikshavn-1, Skagen-2, Rønde-1, and Horsens- 1 wells, the formation is a silt-dominated sequence with localised sandy layers. To the west, in the Nøvling-1, Fjerritslev-2, J-1, K-1, and F-1 wells, the sequence previously assigned to the Frederikshavn Member by Michelsen (1978) is fine-grained, being mainly clay dominated. Therefore, it may be concluded that the Frederikshavn Formation in the Hyllebjerg-1, Skive-1, Kvols-1, Rødding-1, and Oddesund-1 wells marks the westernmost extension of the Frederikshavn Formation (cf. fig. 5 and Michelsen, 1978, figs. 10, 16 and 17). The gamma ray curve in the F-1 well and the SP curve in the Fjerritslev-2 well indicate that thin coarser-grained sequences occur in the uppermost levels of the sequence that was previously named the Frederikshavn Member. The underlying interval, that was previously assigned to the Frederikshavn Member, is best regarded as a part of the Børglum Formation that is time-equivalent with Frederikshavn Formation to the east and, in part, with the Sauda Formation (sensu Vollset \& Doré 1984) to the west (fig. 6 and Michelsen et al. 1984, fig. 2). Another possibility, however, is that the sequence in question belongs to the Sauda Formation, and that the transition between the Frederikshavn and Sauda Formations is located in the offshore part of the Danish Subbasin.

These new considerations concerning the Børglum Formation and/or the possible relationships between the Sauda and Frederikshavn Formations require new studies of the sequence and the establishment of a new reference section. The only well sections presently available are $\mathrm{J}-1$ and F-1. The latter well is the most suitable as the transition to the overlying Vedsted Formation is better defined than in the J-1 well. However, data quality is poor in these two wells and it is hoped that future drilling will provide better data for the definition of the Upper Jurassic lithostratigraphy in this area. 


\section{Acknowledgements}

I want to express my sincere thanks to lic.scient. Gunver Krarup Pedersen and cand.scient. Ole Valdemar Vejbæk who have carefully read the manuscript and suggested many improvements.

$\mathrm{Ph}$.D. Jon Ineson is thanked for correcting the English manuscript. Eva Melskens has produced the drawings, and Heinke Andersen has typed the manuscript.

\section{References}

Boldreel, L.O., 1985: On the structural development of the salt dome province in NW Jutland, Denmark, based on seismic studies. First Break, 3 (8). 15-21.

Christensen, O.B. \& Kilenyi, T.I., 1970: Ostracod Biostratigraphy of the Kimmeridgian in Northern and Western Europe. Danm. geol. Unders. II Række 95.65 pp.

Davey, R.J., 1982: Dinocyst stratigraphy of the latest Jurassic to Early Cretaceous of the Haldager No. 1 borehole, Denmark. Danm. geol. Unders. Ser.B 6. 56 pp.

Deegan, C.E. \& Scull, B.J. (compilers), 1977: A standard lithostratigraphic nomenclature for the Central and Northern North Sea. Rep. Inst. Geol. Sci., No. 77/25, Bull. Norw. Petrol. Direct., No. $1,36 \mathrm{pp}$.

Hedberg, H.D. (ed.), 1976: A Guide to Stratigraphic Classification, Terminology, and Procedure. John Wiley and Sons, New York, London, Sydney, Toronto, $200 \mathrm{pp}$.

Koch, J.-0., 1983: Sedimentology of Middle and Upper Jurassic sandstone reservoirs of Denmark. In: J.P.H. Kaasschieter \& T.J.A Reijers (eds.): Petroleum geology of the southeastern North Sea and the adjacent onshore areas. Geol. Mijnbouw 62, 115-129.

Larsen, G., 1966: Rhaetic-Jurassic-Lower Cretaceous Sediments in the Danish Embayment (A Heavy-Mineral Study). Danm. geol. Unders. II Række 91. 127 pp.

Michelsen, O., 1975: Lower Jurassic biostratigraphy and ostracods of the Danish Embayment. Danm. geol. Unders. II Række 104. 287 pp.

Michelsen, O., 1978: Stratigraphy and distribution of Jurassic deposits of the Norwegian-Danish Basin. Danm. geol. Unders. Ser. B 2. $28 \mathrm{pp}$.

Michelsen, O., 1979: Report on the Jurassic of the Hobro No. 1 and Voldum No. 1 borings, Denmark. Danm. geol. Unders., Årbog 1978, 141-149.

Michelsen, O.(ed.), 1981: Kortlægning af potentielle geotermiske reservoirer i Danmark. Danm. geol. Unders. Ser. B 5. 96 pp.

Michelsen, $\mathrm{O}$., in press: Log-sequence analysis and environmental aspects of the Lower Jurassic Fjerritslev Formation in the Danish Subbasin. Danm. geol. Unders. Ser.A 25.

Michelsen, O., Holm, L., \& Frandsen, N., 1984: Stratigraphy of the Danish Jurassic sequence. International Symposium on Jurassic Stratigraphy Erlangen, III, 756-766.

Pedersen, G.K., 1986: Changes in the bivalve assemblage of an Early Jurassic mudstone sequence (the Fjerritslev Formation in the Gassum-1 well, Denmark). Palaeogeogr., Palaeoclimatol., Palaeoecol. $53,139-168$

Sørensen, E.N., 1986: Seismisk kortlægning af Himmerland Djursland området med særlig vægt på dybdekonvertering. Unpublished Thesis from Aarhus University, $142 \mathrm{pp}$.

Vollset, J. \& Doré. A.G., 1984: A revised Triassic and Jurassic lithostratigraphic nomenclature for the Norwegian North Sea. NPD-Bulletin No. 3, Oljedirektoratet, $53 \mathrm{pp}$ 
This paper comprises a revision of the Jurassic lithostratigraphy in the Danish Subbassin.

The Haldager and Bream Formations are abandoned. The Haldager Sand, and the Flyvbjerg, Børglum and Frederikshavn Members are elevated to the rank of formations. 